\title{
Constructing the economic-historic context of 1 Peter: Exploring a methodology
}

Author:

Fika Janse van Rensburg ${ }^{1}$

\section{Affiliation:}

${ }^{1}$ Faculty of Theology, North-West University, Potchefstroom Campus, South Africa

\section{Correspondence to:}

Fika Janse van Rensburg

email:

fika.jansevanrensburg@ nwu.ac.za

Postal address:

Private Bag X6001, Potchefstroom 2520,

South Africa

\section{Dates:}

Received: 15 Aug. 2010

Accepted: 30 Sept. 2010

Published: 07 June 2011

How to cite this article: Janse van Renseburg, F., 2011, 'Constructing the economic-historic context of 1 Peter: Exploring a methodology', HTS Teologiese Studies/ Theological Studies 67(1), Art. \#939, 11 pages. DOI: 10.4102/hts.v67i1.939
(C) 2011. The Authors. Licensee: OpenJournals Publishing. This work is licensed under the Creative Commons Attribution License.
This article explored a methodology to construct the economic-historic context of the addressees of 1 Peter, which could serve as basis for an economic interpretation of 1 Peter and other New Testament books. After discussing 1 Peter as letter, external sources were used to construct the economic-historic context of the addressees of 1 Peter. This construction was then refined utilising the letter itself, by identifying, categorising and interpreting the economically relevant portions of 1 Peter. Finally, the economic-historic context of the addressees of 1 Peter was concluded and the method summarised.

\section{Introduction}

Various scholars have made important contributions to some of the economic issues in the New Testament and to the history of early Christianity in relation to the ancient economy. These treatments, however, have tended to be isolated studies focused on particular questions. ${ }^{1}$ Furthermore, very few of these investigations have been undertaken from the standpoint of the economic histories ${ }^{2}$ of Greece and Rome or informed by economic theory in the Graeco-Roman world. In short, the economies and economic theories of antiquity have never been related to the history of early Christianity in any kind of comprehensive, systematic way. ${ }^{3}$ Recently, however, an important volume edited by Bruce Longenecker and Kelly Liebengood was published: Engaging economics: New Testament scenarios and early Christian reception (Longenecker \& Liebengood 2009). Two contributions in this volume are relevant to the present article, 'Methodological issues in using economic evidence in interpretation of early Christian texts' (Oakes 2009:7-34) and 'Aliens and strangers? The socio-economic location of the addressees of 1 Peter' (Horrell 2009:176-204).

This article wants to contribute towards a delineation of the relationship between early Christianity and the ancient economy by exploring a method for constructing the economic-historic context of the addressees of 1 Peter. This could then serve as basis for an interpretation of 1 Peter within this economic-historic context. ${ }^{4}$

I approach the topic 'economy' 5 as comprehensively as possible, looking at all relevant data, whether dealing with individual personal finance or with the economies of the relevant towns and countries as far as such data is available. By beginning with the relevant ancient economies themselves and viewing the 'economy' broadly, I want to contribute towards not only gaining a better understanding of the Graeco-Roman world, but also to ground the economic study of 1 Peter securely within its ancient socio-historical context.

To interpret 1 Peter within its economic-historic context, it is necessary to construct this context. Linking on to the definition of the task of economic history by Morris, Saller and Scheidel (2007:1), I

1.The most important contribution is probably that of Grant (1977), who covers both the New Testament and the early church, offering treatments of 'Taxation and Exemption' (44-65), 'Work and Occupations' (66-95), 'Private Property' (96-123), 'The Organization of Alms' (124-45) and 'Temples, Churches and Endowments' (146-164). See also Bassler (1991); Gnuse (1985); Hengel (1974); and Johnson (1977).

2.The task of economic history is 'to explain the structure and performance of economics through time' (Morris, Saller \& Scheidel 2007:1). In this definition 'performance' refers to the typical concerns of economists (for example, how much is produced, the distribution of costs and befits, or the stability of produpion). 'Structure' is those chara (for example, hich of distribution 'Through tic ' explicit theorising and potential of refutability.

3.The neglect of the issue of 'religion and the economy' is especially true in regard to early Christianity. Because early Christianity usually has been thought of simply as a religious movement (as opposed to a country), scholars have paid scant attention to many of its economic aspects and to the role that it played in the ancient economy. Consequently, the economic history of early Christianity has not received the attention it deserves, nor is there a commentary on the New Testament that focuses on the economic aspects of passages. However, the works of Hansen and Oakman (2008), Oakman (2008) and Stegemann and Stegemann (1999), make a valuable contribution by exploring facets of the economy and society of the Mediterranean World of the 1st century.

4.Although most scholars of religion readily acknowledge the role that religion plays in the economy and the economic aspects of religion itself, substantially less attention have been paid to the issue of 'religion and the economy' than historians and economists have to the issue of 'history and the economy'. For a recent contribution on the role of possessing property in religious and social life, see (2004).

5.By 'economy' I mean not simply the production and consumption of goods and services, but such economic factors as attitudes toward wealth and poverty, the problem of unemployment, the role that both government and religion played in addressing economic problems, what occupations were encouraged and the relationship of work to charity. 
view the task of constructing the economic-historic context of 1 Peter to explain the structure and performance of economics in the area where the addressees of 1 Peter lived. To explain the 'structure' means to theorise about the characteristics of society, which are purported to be the basic determinants of performance (like political and economic institutions, technology, demography and ideology of a society), with the potential of refutability. Explaining the 'performance' entails hypothesising about the typical concerns of economists (like how much is produced, the distribution of costs and benefits and the stability of production), with the potential of refutability.

I hope to build on 20th century advances in understanding institutions and ideology by attempting to clarify the relationships between structure and performance. Morris, Saller and Scheidel (2007:7) see this endeavour as the second of three main challenges facing Graeco-Roman economic historians in the early 21 st century. ${ }^{6}$ This requires continued engagement with the social sciences.

In the following, I discuss 1 Peter as letter. I then construct the economic-historic context of the addressees of the letter utilising external sources afterwards. Next, this construction is refined utilising 1 Peter itself: the economically relevant portions of 1 Peter is identified, categorised and interpreted. Finally the economic-historic context of the addressees of 1 Peter is concluded and the method used is evaluated.

It is, however, necessary to first share my view of 1 Peter as letter, because this impacts on the spatial and temporal issues involved in constructing the economic-historic context of the addressees of 1 Peter.

\section{First Peter as Letter The date and authorship of 1 Peter}

Together with quite a number of recent scholars, I view 1 Peter as a genuine letter and that it is, like 2 Peter, Galatians, Ephesians, James and Jude, a circular letter (Achtemeier 1996:61-62; Aune 1987:159; Doty 1973:18; Elliott 1986:11; Goppelt 1978:45; Thurén 1989:93-94). 1 Peter also exhibits definite characteristics of the contemporary Jewish diaspora letter, as do the other New Testament circular letters (Aune 1987:185; Schnider \& Stenger 1987:24-38).

Research has given no persuasive arguments that Peter the apostle could not have written the letter, having dispatched it from Rome. ${ }^{7}$ Therefore, along with a number of scholars (Selwyn 1952:27-33; Thurén 1989:25-28; Van Unnik 1980a:80; Guthrie 1970:792-796), I take the self identification of the

6.The three main challenges facing Graeco-Roman economic historians in the early 21st century, according to Morris, Saller and Scheidel (2007:7), are '(i) to find ways to document performance more accurately; (ii) to build on twentieth century advances in understanding institutions and id advances in uncture and performance; and (iii) to pursuelarionship structure and performance; and (iil)

7.The origin of the letter is not disputed; scholars generally agree that it was sent from Rome, for example, Van Unnik (1980a:81) and Achtemeier (1996:64).

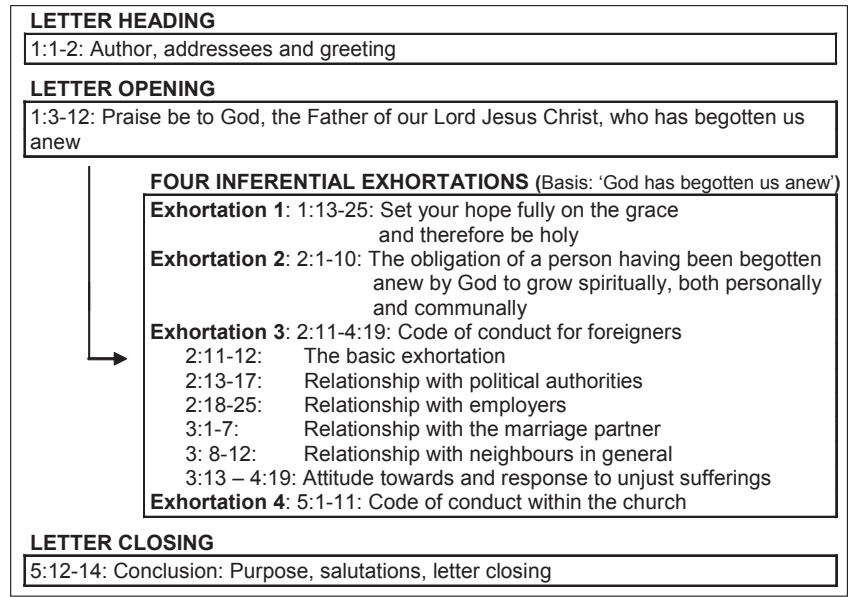

FIGURE 1: A synopsis of the argument of 1 Peter.

author as a matter of fact. This viewpoint implies that the letter is to be dated before $70 \mathrm{AD}{ }^{8}$

\section{The argument of 1 Peter}

As frame of reference for the identification and interpretation of the relevant portions in 1 Peter, I accept the argument of this letter proposed Van Rensburg (2006:481-488). According to this interpretation, the basic statement in 1 Peter is that the Father has begotten anew the first readers (патทे тои̃ kupíou

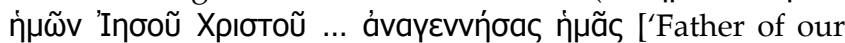
Lord Jesus Christ ... who has begotten us anew'], 1:3) (1:312). This statement functions as the basis for four inferences that are given as four exhortations:

- $\quad$ set your hope fully on the grace and therefore be holy (1:13-25)

- the obligation of a 'new' child of God to grow individually, as well as together with fellow-believers $(2: 1-10)$

- code of conduct for nápoıкo [resident foreigners] and парєпі́бпно [visiting foreigners] (2:11-4:19)

- code of conduct within the church (5:1-11).

This view of the argument of 1 Peter and specifically the coherence between the letter opening (1:3-12) and the body of the letter can be represented in Figure 1.

The section 1 Peter 3:13-4:19 (Attitude towards and response to unjust sufferings) covers a large portion of the letter. Therefore it is necessary also to give my interpretation of the inter-relationship of the subsections of this part of the letter:

- In 3:13-17, the third exhortation (2:11-12) is applied to the attitude towards and response to unjust suffering, stating inter alia that only Christ should be revered as Lord.

- The section 3:18-22 gives the reason for revering only Christ as Lord, pointing to the fact that Christ is in the position of authority after all powers had been subjugated to him.

8.Elliott (1981:87) dates the letter 73-92 AD. The dates proposed by three standard commentaries are: Selwyn (1952:62) 63 AD, Goppelt (1978:64-65) 65-80 AD and Brox (1979:38-41) 70-100 AD. Balch (1981:138) dates it 65-90 AD and Van Unnik (1980a:70): 'before the year 70'. Others date the letter late in the 1st century and view it to be pseudonymic (see e.g. Aune 1987:218; Beare 1970:48; Achtemeier 1996:49-50 and Feldmeier 1992:199). 


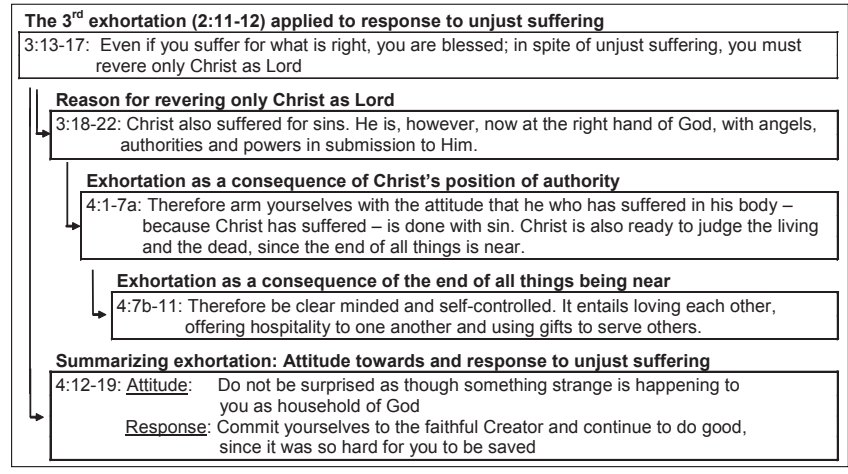

FIGURE 2: The argument of 1 Peter 3:13-4:19.

- Christ's position of authority, however, has a consequence for the way the readers should view their suffering (4:1-7a). The addressees are also assured that their suffering will not last forever, because the time when Christ will judge the living and the dead is near.

- In 4:7b-11, the addressees are exhorted to a specific lifestyle as a consequence of the statement that the end of all things are near.

- The final section, 4:12-19, summarises the whole of 3:134:11 by indicating how the addressees should view their unjust suffering and how they should respond to it.

This interpretation of the argument of 3:13-4:19 can be represented in Figure 2.

Having given my interpretation of the argument of 1 Peter, I will now, in the following section, construct the economichistoric context of the addressees.

\section{The Economic-Historic context of 1 Peter Constructed from External Sources}

The economic-historic context is constructed in a two-step process by utilising first sources other than 1 Peter and then the text of 1 Peter itself. To begin with, I focus on relevant economic tendencies in the 1st century Graeco-Roman world in general and afterwards construct the structure and performance of economics in the area where the addressees of 1 Peter lived.

\section{Economic tendencies in the 1st century Graeco- Roman world}

In the 1st century, the word oikovouía [household management] did not refer to the study of how nations and societies produced, distributed and consumed goods, but rather designated the management of the private household (oî́os [household]), ${ }^{9}$ the basic unit of production as well as consumption in the Graeco-Roman world (Saller 2007:87). Ancient households (typically comprising a two-generation

9.The management of the private household is, for example, the subject of Xenophon's Oikonomikos (before the middle of the 4th century BC) as well as Philodemus' On Household Economy. Similarly, Pseudo-Aristotle's Oikonomika is principally concerned with the good of the family. These documents also attest to the gendered division of labor (see Saller 2007:87) nuclear family, free and unfree dependants, slaves, animals, land and other property; see Saller 2007:91-92) endeavoured to be as self-sufficient as possible (Cartledge 1996). In a similar fashion, so did most cities and nations, but the vicissitudes of life (for example weather, war and illness), as well as the opportunities created by trade guaranteed that individuals, communities and nations were dependent on goods and services from external sources to various degrees.

Some classical scholars assert that relevant economic thought did not arise until the Enlightenment, as early economic thought was based on metaphysical principles that are incommensurate with contemporary dominant economic theories such as neo-classical economics (Meikle 1995; Finley 1970). However, several ancient Greek and Roman thinkers, especially Aristotle and Xenophon, made various economic observations. Many other Greek writings also show understanding of sophisticated economic concepts.

It is acknowledged that, in dealing with issues of exchange and accumulation, ancient economic theory gave greater attention to ethical concerns than to technical considerations. In addition, it did not share the frequent present day assumption about the autonomy of economics (Nussbaum 1996).

The economies of ancient Greece and Rome, as well as the economies of the most important Hellenistic kingdoms, were not only diverse but changed over time. Major shifts from exclusively rural and village-based agricultural economies to those that included port cities, large mining operations and major urban centres, populated with many transient workers, foreigners and immigrants took place.

Trade and commerce in the Roman world from the late 1st century BC until the 4th century AD underwent some fundamental alterations, yet there were some aspects which remained basically unchanged (Sidebotham 1996). At the beginning of the period, the Mediterranean basin contained a number of independent or semi-independent political states in commercial-diplomatic contact and conflict with one another and with Rome. The larger states, Seleucid Syria (until 64 BC), Ptolemaic Egypt (until 30 BC), Hasmonean and later Herodian Judea (until the 1st century AD), Nabatean Arabia (until AD 106), states in Asia Minor like Galatia (until 25 BC), Cappadocia (until AD 18), and Commagene (until the 1 st century AD) and other smaller eastern powers, nominally independent client states of Rome and autonomous entities, as well as the few independent states in the West (the kingdom of Mauretania until the 1st century AD), interacted as commercially independent, if not completely politically autonomous states. Falling transport and communications costs in this era allowed seaborne trade of staples such as food, metals and stone in unprecedented quantities (Morris, Saller \& Scheidel 2007:10).

By the 4th century AD, the entire Mediterranean basin had been unified politically under the aegis of Rome. Political unification also brought with it a unified system of coinage 
and laws regulating the commerce, although not a completely unified economy. This 4 th century economy was less laissezfaire than that of the 1st and 2nd centuries. The state and the church took an increased interest and role in commerce, often at the expense of the independent entrepreneur. This transformation took place gradually from the 1st century $\mathrm{BC}$ until the 4th century AD, the by-product of a series of patchwork-stopgap solutions to economic problems rather than a deliberate long-term policy initiated by the Roman central government.

The Greek and Roman states were strong enough to protect property rights, but too weak to predate on their subjects so viciously that they smothered economic activity (Morris, Saller \& Scheidel 2007:11). The structures of citizenship were both positive and negative factors. On the positive side, it is clear that 'free male citizens controlled their own fates to a degree that few ancient societies matched' (Morris, Saller \& Scheidel 2007:11). On the negative side:

The ideology of egalitarian male citizenship drove many forms of economic activity to the margins of respectable society, sometimes creating a demi-monde dominated by aliens, women and slaves; the high cost of citizen labour created strong demand for chattel slaves in some periods and places.

(Morris, Saller \& Scheidel 2007:10)

Utilising information from the New Testament, Hock (1985) offers a helpful description of economics in New Testament times. ${ }^{10}$ He uses the terms 'city, ' countryside' and 'wilderness' as general analytic categories for classifying and organising the New Testament data into a coherent description of the ancient economy. These three terms are taken from Mark 1:45 , where the author of this Gospel describes John as preaching 'in the wilderness' and as drawing people to him 'from the whole Judean countryside and the city of Jerusalem'.

Sidebotham's description of the commerce in the Roman Empire (1996) is very helpful. ${ }^{11}$

Although the rising volume of trade allowed some exploitation of comparative economic advantages around the Mediterranean, accomplished largely through private enterprise and markets, Morris, Saller and Scheidel (2007) warn that:

States remained major economic actors; markets were fragmented and shallow, with high transaction costs; investment opportunities were limited; money and markets generated

10. Hock (1985) also points to some other sources and indicates their value for a study of the ancient economy. One of the literary sources he mentions is Longus' Daphnis and Chloe, which, despite some pastoral flights of fancy, provides a lengthy and coherent account of the lives of herders in the countryside. Complementing Longus, are the Letters of Alciphron, which give many experiences of farmers and fishermen. For the life of hunters on the edge of the countryside and wilderness there is Dio Chrysostom's seventh Oration and for considerable attention to brigands there is the Ephesian Tale by Xenophon (although too early to be of any real significance for the 1st century AD). Lastly, the lives of householders, artisans and other urban characters find detailed, if humorous, treatment in the Satires of Lucian. Evidence on papyrus and stone is the staple of historians of the ancient world and amongst this evidence are many documents such as apprentice contracts, receipts and records of gifts to temples that detail virtually every aspect of ancient economic life.

11.Sidebotham (1996) gives a description of commerce in the Roman Empire unde the following headings: Imperial Commerce, Monetarization of the Roman Economy, Inflation, Roman Banking, Transportation, The Merchant/Entrepreneur Class, Slavery and External Trade. intense ideological conflicts; and the economy remained miniscule by modern standards.

(Morris, Saller \& Scheidel 2007:10)

Against this background of the general tendencies of the economics of the 1st century Graeco-Roman world, in what follows I narrow the focus down to the era when and area where the addressees of 1 Peter lived. ${ }^{12}$

\section{The structure of economics in the area where the addressees of 1 Peter lived}

\section{The geography of the areas identified in the address of 1 Peter}

Four areas are designated in the address in 1 Peter 1:1:

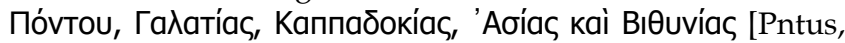
Galatia, Cappadocia, Asia end Bithynia] ${ }^{13}$ This is part of what is referred to as 'The Eastern Mediterranean', which around AD 106 included Achaea and Macedonia in modern Greece and the Republic of Macedonia (former Yugoslavia), various divisions within the nation state of Turkey (Asia, Bithynia and Pontus, Galatia, Cappadocia, Lycia and Pamphilia, Cilicia), as well as Syria, Judaea (later Palestine) and Arabia in the Levant (Alcock 2007:674). Greek was the common language of the region's elite, but numerous local languages survived under the empire.

The area had a variety of micro-climates, with direct implications for agricultural success and the concomitant need for exchange. This contributed to the fact that economic opportunities and options varied substantially, depending where in the region one operated (Alcock 2007:674-5). Coastal or near-coastal communities had access to water transport, with harbour complexes, for example the one at Ephesus, whilst the high tablelands of Anatolia remained relatively landlocked.

\section{The demography of the areas identified in the address of 1 Peter}

Long before the Greeks brought the plains and southern and western coastal regions of Asia Minor under their control, tribes of Hittite origin lived in the valleys and dales of the Taurus Mountains (Breytenbach 1998:358). Since 133 BC, these areas slowly came under Roman rule. The Roman government, however, had little interest in distant areas. Therefore they gave areas such as the northern cliffs of the Taurus Mountains, where the Isaurians and the Hammonadians lived, to local small kings of Asia Minor, such as King Amyntas of Galatia. By subjecting the local population, he could occupy the region with the approval of Rome and thus maintain stability there. This province was an administrative unit which encompassed in the north the region of Galatia and in the south the areas of Pisidia, Lycaonia and Isauria (Breytenbach 1998:358).

12.Alcock (2007:671) warns that general studies of the Roman economy tend to be dominantly orientated towards the developed world. In her own approach she is careful not to do this, but to work with evidence from the relevant area.

13.Achtemeier (1996:57), after surveying the scholarship on the matter, concludes that 'the best conjecture is that the intended readers of this epistle represented the broad spectrum of people living in northern Asia Minor'. 
The Augustan takeover appears to have inaugurated and extended an epoch of peace, taking disruptions of a more local character for granted. Only in the 3rd century was the pax Romana significantly universally disrupted. There was, however, a price to be paid: taxation (in kind and in cash) became a regular and more or less universal element in the economic configuration of the region (Alcock 2007:675-676).

Two essential parameters govern and are governed by the workings of the economy: the number of people in a region and their distribution in space (Alcock 2007:676). The four areas mentioned in 1 Peter 1:1 cover about a quarter of a million square kilometres. Estimates of the number of inhabitants during the last quarter of the 1st century range from four to eight million. The topography of the area varies much and it had different nations with diverse cultures, languages, faiths and political histories (Elliott 1981:60-61). There were little urbanisation and military colonisation (Broughton 1938:734). There is evidence that cities in parts of Cappadocia never had more than a 3rd of the surrounding area under their administration (Broughton 1938:738). One of the consequences was that most of the people lived in small independent towns and villages. It furthermore seems as if the borders of urbanisation were the borders of hellenisation as well.

Alcock (2007:677) shows that at least Ephesus could potentially have approached 100000 inhabitants; most city units, however, comprised populations in the range of 10 000-15 000, with an additional proportion of people dwelling outside the urban centre. Mitchell (1993:243-244) concurs, arguing that relatively few of the estimated 130 cities in the various Anatolian provinces would have had more than 25000 inhabitants.

Seemingly, there were no group loyalties surpassing local and regional differences (Elliott 1981:62), although at least religions, and Roman citizenship could have been such unifying factors.

The main source for information about Jewish communities in the Roman provinces in Asia Minor is epigraphic and archaeological material (Breytenbach 1998:332). ${ }^{14}$ Schürer (1973:17-38), as well as Stern (1974:153), gives evidence from inscriptions and other documents that there were Diaspora in all the areas mentioned in 1 Peter 1:1. ${ }^{15}$

There is not enough data to allow full clarity on the number of Jews in these areas, ${ }^{16}$ but estimations range from a quarter

14.Alcock (2007:673) observes that the eastern Mediterranean still lags behind othe parts of the Roman Empire in the availability of archaeological evidence, both in raw form and in broader synthetic studies. As the corpus of archaeological dat grows, adventurous and closer grained studies can be done (see Alcock 2007:696).

15.Breytenbach (1998:365) in his discussion of inscriptional evidence of the presence of Jews, proselytes and God-fearers, mentions an inscription ( $\mathrm{ClJ} \mathrm{I}{ }^{2} 683 \mathrm{a}$ ) from Panticapaeum at the Black Sea confirming that God-fearers were distinguished from Jews and proselytes; the inscription refers to the 'synagogue of the Jews and the God-fearers'.

16.Chaefer (1949:1701) gives evidence for about 300 years earlier. Then there were about $1000 \pi$ ápOIKOI [visiting foreigners] for every 6000 citizens. It seems valid to accept that the number of $\pi$ ápoIKol in these areas increased rather than decreased towards the 1st century $A D$, so that the ratio could even have been higher that 1:6 by the 2 nd half of the 1 st century $A D$. of a million Jews out of a total population of 4 million (Reicke 1964:302-313), to one million Jews from a total population of eight million (Broughton 1938:815). A reason for the growth in numbers was that during the 1st century $\mathrm{AD}$, proselytism experienced a boom (Stern 1974:117). There is also evidence that during the 1st century there was much stability in the economies of the Diaspora-Jews in these areas (Applebaum 1976:702).

These Jews, although fully participating in the Hellenistic culture and society, still viewed themselves as Jews, in spite of living abroad (Safrai 1974:185). Frequent visits to Jerusalem, also by proselytes (Safrai 1974:199-205) witness to the fact that Judea was viewed as home.

It is therefore quite possible that, also in these areas, Christianity moved into the world via the bridge of Hellenised Diaspora Judaism (Breytenbach 1998:330).

\section{The performance of economics in the area where the addressees of 1 Peter lived}

In this section I theorise about the typical concerns of economists (like how much is produced, the distribution of costs and benefits, or the stability of production in the relevant societies), focusing on production, distribution and consumption. The work done by Alcock (2007) has been most helpful in this endeavour.

\section{Production}

Alcock (2007:678-682) paints a clear picture. The mosaic of landownership was exceedingly complicated. There was trend towards increasing stratification in the control of agricultural wealth and the external interventions worked in favour of expansive, often imperially privileged, landowners. The minor landowners, whose small-scale production continued to be important in the Roman Empire, were still operative. Tenancy, together with the periodic hiring of free labour, was a very common means of organising production. In the early imperial period there was an increase in agricultural activity and intensity of production. In some areas this was linked to the market offered by a nearby conurbation, for others it might have been as a result of the stimulus of local natural resources (such as timber, ore, or marble), their exploitation and the need to feed specialist workers. "There must have been successful surplus production of basic necessities to feed, clothe and otherwise supply and support those units' (Alcock 2007:682).

Alcock (2007:682-686) gives a survey of non-agrarian production, including ceramics, textiles and mining and quarrying.

\section{Distribution}

Alcock (2007:686-692) considers the distribution of goods in space, at the local, regional and long distance scale. 'Local exchange' covers the ambit of a particular city or large village, 
or a close nexus of these entities. 'Regional distribution' is the movement of goods across distances exceeding travelling times between neighbouring cities, yet remaining in the ambit of the eastern provinces. There is clear evidence of an increasingly vibrant network of regional interaction. 'Long distance' trade refers to the distribution of raw materials or finished products either to Italy and the west, or their conveyance to (or through) the east from beyond the bounds of the empire. The agents involved in these interactions were the Roman state, shippers [naukleroi] and merchants [emporoi], together with negotiatores of western origin (Alcock 2007:691).

\section{Consumption}

The 3rd axis, consumption, drives the dynamics of both production and distribution. Alcock (2007:692-694) gives a summary of this axis, the most difficult of the triad. There is a basic division between public and private and also huge gulfs of difference between super-cities and villages, between the urban aristocracy and the rural poor. Local and regional efforts largely provided what civic populations needed to live.

There is great variety in civic access to and use of, goods, as well as in the factors underlying such variation. Up and down the social scale the acquisition and utilisation of goods extended beyond the immediate local sphere. The denunciation in Revelation 18:12-14, revelling in the destruction of a great city and its material abundance, provides a list of goods that would have been typical:

${ }^{12}$ cargo of gold, silver, jewels and pearls, fine linen, purple, silk and scarlet, all kinds of scented wood, all articles of ivory, all articles of costly wood, bronze, iron and marble, ${ }^{13}$ cinnamon, spice, incense, myrrh, frankincense, wine, olive oil, choice flour and wheat, cattle and sheep, horses and chariots, slaves-and human lives. ${ }^{14}$ 'The fruit for which your soul longed has gone from you and all your dainties and your splendour are lost to you, never to be found again!'

$(\operatorname{Rv} 18: 12-14)$

To conclude this section then, the plurality of the ancient economy in the Roman east is clear. Alcock (2007:695) suggests a spatial perspective on the organisation of economic process, be it for local patterns, regional cadences, or interregional flows, as one way to follow out alternative sets of behaviour, whilst still allowing for their mutual influence.

On the issue of growth, Alcock sees many indicators to point in the following direction:

The development of urban hierarchy, the increase (however modest) in overall population, the expansion of rural settlement, the density of merchant networks, the material evidence for more exchange and more consumption of more types of goods. ${ }^{17}$

(Alcock 2007:696)

17.Icock (2007:696), however, adds: 'Both more adventurous and closer grained studies are required, especially those calling upon the growing corpus of archaeological data.... Far more thought needs to be given to the manner in which cultural, ethnic, or religious difference skewed economic choice and behaviour in cultural, ethnic, or religious difference
different parts of the eastern empire'.

\section{The Economic-Historic Context of 1 Peter Constructed from 1 Peter}

To construct the economic-historic context of the addressees of 1 Peter from the text, the relevant utterances need to be identified and categorised. This can be done in different ways. In my own identification and categorisation, care has been taken to use concepts and categories suggested by the text, as well as by the construction of the economic context of the addressees from external sources and not to superimpose concepts and categories on the text of 1 Peter. ${ }^{18}$ The same care has been taken to be emic in approach, optimally utilising the economic theory relevant to the 1st century $\mathrm{AD}$ and the probable economic circumstances of the addressees.

The relevant portions of 1 Peter can be categorised into four main sections:

- the па́рогко каї парєпıби́но [resident and visiting foreigners] label that the author gives the addressees

- teachings and exhortations concerned with economic matters

- mention of the precious metals silver and gold

- the metaphoric use of economic concepts and terminology.

The contribution each of these utterances makes towards constructing the economic-historic context of the addressees of 1 Peter is now investigated.

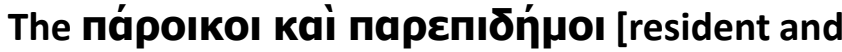 visiting foreigners] label of the addressees}

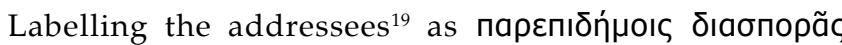
([visiting foreigners of the Diaspora], 1:1;2:11) and nápoıкoı] ([resident foreigners], 2:11) and referring to their sojourn as the time of their парокі́as [dwelling as resident foreigners] (1:17) do not imply a mere metaphoric, figurative state of Christians being strangers in the world because they are citizens of heaven. ${ }^{20}$ Rather, the addressees were, already before their conversion to the Christian faith, 'visiting and resident foreigners' in the literal socio-political sense of the words. $^{21}$

18.Morris, Salter and Scheidel (2007:5-6) correctly states that 'the changing world we live in surely makes certain questions about the past seem more interesting than others and may direct our attention to bodies of evidence that previous generations of scholars have overlooked'. They are, however, also correct in stating that 'it does not shape the data themselves, or the logic of our methods'.

19.Different scholars have adequately surveyed the scholarship on the identity and circumstances of the addressees of 1 Peter. The most exhaustive of these are Goppelt (1978:161-177) and Achtemeier (1996:50-58) and especially Feldmeier (1992). See also the more recent contribution by Seland (2005).

20.Elliott (1981:32) argues convincingly against such a spiritualisation of nápoIKOI or парoıкía [resident foreigners or dwelling as resident foreigners] in 1 Peter as being contra the social consciousness that is obvious from its use in early Christian and contra the social consciousness
apocalyptic Jewish writings.

21.Much research has been done on the social pyramid of the 1st century GraecoRoman society. This research shows that it is not possible to differentiate absolutely

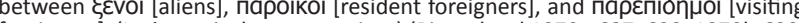
foreigners] (Latin equivalent: peregrinus) (Bietenhard 1979a:687, 690, 1979b:690,

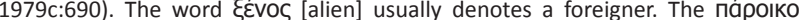
were resident foreigners and the парєпínน 1952:118; Schmidt \& Schmidt 1977:842; Bietenhard 1979b:690). Schaefer lists all the occurrences of nápoIkoc [resident foreigner]. It becomes clear that in a list of the inhabitants of a city the nápoIKo [resident foreigners] were al in a list of the inhabitants of a city, the napolkol [resident foreigners] were always after the no $\lambda$ ITal [citizens], but before the $\xi \dot{\varepsilon V O I}$ [aliens], as well as the freed person and the slaves. He (1949:1695-1699) also shows that the napolkOI [resident of

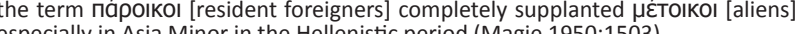
especially in Asia Minor in the Hellenistic period (Magie 1950:1503). 
There is, however, apart from being foreigners in the literal socio-political sense of the word, a second level on which they (or at least some of them) are парєпıбń foreigners] (סıабпорãc [of the Dispersion]) and пápoıко [resident foreigners]. This is the fact that they could have been, before their conversion, proselytes and God fearers ${ }^{22}$

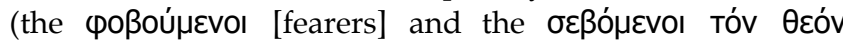
[those honouring God] as has been argued by Van Unnik (1980a:72-74).23 Labelling the addressees as пápoıко кai

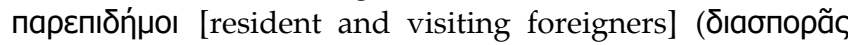
[of the Dispersion]) therefore does not merely describe their social position, it could indicate their previous status as 'God-fearers' as well.

The author of 1 Peter links on to this sense of пápoıко кai

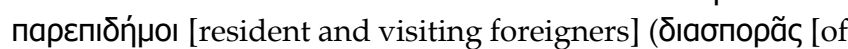
the Dispersion]), transforming the (in some ways) abusive title to a proud self-identification by giving it a deeper and specific theologically positive sense. In a way it is part of the adoption of the honorific titles of the Old Testament people of God and in another way it has been transformed into a proud self-identification in its own right (Feldmeier 1992:104). ${ }^{24}$

Van Unnik (1980b:113) has already acknowledged that the historical data on the identity and circumstances of the addressees is not as extensive as we could wish, or sufficient to allow us an exact definition of the situation. The data from the epistle, however, is sufficient to allow a valid construction of the situation..$^{25}$

The letter does not give any explicit cause for the nápoıкo kaì парєпıঠп́ $\mu$ о [resident and visiting foreigners] status of the addressees. It is improbable that official persecution was the

22.Richard (1986:123), on the other hand, is of the opinion that the addressees were simply Gentile Christians. He motivates his viewpoint from 1 Peter 1:14 and 1:18 and from the fact that the typical Jewish issues are not addressed in the letter Van Unnik (1980a:68) shows, however, that 'passages, which show parallels with proselytism, are not to be found in a single chapter but throughout the epistle. The similarities appear constantly wherever the situation of the addressees of the epistle is being treated and wherever the work of Jesus Christ and its significance epistle is being

23.Van Unnik (1980a:53) says that 'in 1 Peter the Christians are compared to the pagans who join the people of the Covenant through the proselytes offering'

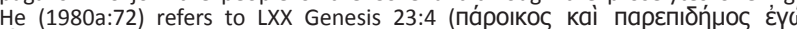

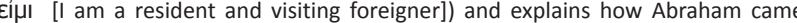
to be viewed as the 'father of the proselytes', having been regarded as the first

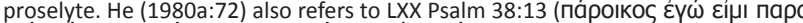

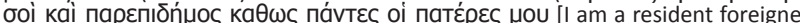
and a visiting foreigner before you, like all my fathers]) to show the typical and simultaneous (as happens in 1 Pt 2:11) use of nápolkos [resident foreigner] and simultaneous (as happens in 1 Pt 2:11) use of nápolko S [resident foreigner] and

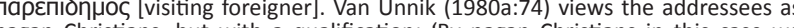
pagan Christians, but with a qualification: 'By pagan Christians in this case we should understand those who had once been pagans but whose views on the way

24.Feldmeier (1992:104) is even more specific in his conclusion: 'Das Originelle und Zukunftsweisende am 1.Petrusbrief ist also dies, dass er nicht nur im Bezug auf biblische Gestalten oder auf dem Umweg über die philosophiische Tradition die Fremdheid in der Gesellschaft als ein positives moment zu deuten versucht, sondern dass er in einem kühnen Rückgriff auf eine relativ schmale biblische und jüdische Tradition die negativen Erfahrungen von Nicht-Identität als Spezifikum christlicher Identität interpretiert'. (The original and future orientated characte of First Peter is also the fact that it not only tries to find in the reference to biblical figures or from the detour of the philosophical tradition a positive element in the congregation's status as aliens, but also through a bold new understanding of the relatively narrow biblical and Jewish tradition of the negative experience of being without identity, interpret this tradition as a specific Christian identity.)

25.Goppelt (1978:161-177) offers an extensive survey and evaluation of a variety of scholarly work on the circumstances of the addressees. Thurén (1989:29) also gives a valuable survey, as does Achtemeier (1996:51-58). cause. ${ }^{26}$ The backdrop rather seems to be the socio-political status of the Christian groups in the Diaspora, their daily relationships with Jews and other non-Christians and the difficulties that they, as 'resident and visiting foreigners ${ }^{27}$ had to face daily. Their suffering, therefore, was most probably not caused by official persecution, but by spontaneous local social ostracism ${ }^{28}$ (Balch 1981:95; ${ }^{29}$ Elliott 1976:252; Elliott 1986:14; ${ }^{30}$ Van Unnik 1980a:79-80;11 Van Unnik 1980b:113,116; see also Moule 1956-1957:1-1132).

The hardships were, by and large, experienced within the smaller circle of the household. ${ }^{33}$ The kúpıos [owner] had more or less full authority over his wife or wives, children, servants and slaves (see $1 \mathrm{Pt}$ 3:1). When the Kúpıoৎ did not convert to the Christian faith when any member of the household did, it could result in severe discrimination against those who converted, with negative economic consequences. The kúpıos

26.Contra Beare (1970:188). See Elliott (1976:251-252) and Richard (1986:126) for a good summary and rejection of the viewpoint that official persecution was the cause for their status as foreigners. One of the reasons for the rejection of the cause for their status as foreigners. One of the reasons for the rejection of the
official persecution theory is that there is no consensus amongst historians on official persecution theory is that there is no consensus amongst historians on
when the official persecution of Christians started. Frend (1967) and McCaughey (1969:27-40) are of the opinion that the persecution started quite early, whilst (1969:27-40) are of the opinion that the persecution started quite early, whilst
Lewis \& Reinhold (1966:581-582) and Judge (1960) thinks that it commenced later.

27. Having па́роІко૬ [resident foreigner] status in the 1st century $A D$ already implied hardships. The חápoIkol [resident foreigners] had no political rights. Berger (1953:626) shows that this entailed restrictions such as the following: They were

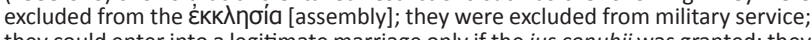
they could enter into a legitimate marriage only if the ius conubii was granted; they could not make a will in the same way Roman citizens could and they could not act could only enter into trade negotiations with a Roman citizen after having been granted the ius commercii.

28.Breytenbach (1998:341) shows that ostracisation by the Jews was typical. They did not socialise with people who did not enter Judaism (Jos. Ap. II:210) and they viewed the gentile nations as 'lawless'. The Jews were often accused of being viewed the gentile nations as 'lawless'. The Jews w
'haters of people' (see Tacitus, Hist. V:1 = GLAJJ II 281.

29.Balch (1981:95) is very specific in his counter argument: 'Rather, certain slaves and wives converted to Christianity; therefore, persons in Roman society reacted by accusing them of being immoral, perhaps seditious and certainly insubordinate'.

30.Elliott (1986:15) summarises his view on the circumstances of the addressees in the following way: 'As a result of spatial dislocation from the homeland (the former Palestinian "klêronomia", 1 Pet. 1:4), religious and ethnic dissociation from Judaism (2:4-10) and social alienation in the "diaspora" (4:2-4), the Christian mission became a movement of pilgrims and aliens without a geographical home (a 'patria') or the political security of a "polis" or citizenship'.

31.Van Unnik (1980a:79-80) says: 'Nowhere do we read that they suffered from the pagan authorities. ... We think of the pagan surroundings and the persecution pagan authorities. ... We think of the pagan surroundings and the persecution which might have arisen there, but we read nothing about that either. Is it not
more obvious to think about persecution by the Synagogue? ... That is why Christ, more obvious to think about persecution by the Synagogue? ... That is why Christ,
who Himself underwent betrayal and death at the hands of the Jews, can be an example to them (chapter ii and iii). This too fits perfectly into the picture that we get in Acts of the earliest mission. There, again and again, it is the Jews who resist and slander Paul and his companions (see Ac xiii 50; xiv 19; xvii 5, 13)'.

32.As to the cause of the persecution Lohse (1954:73) is vague: ,Der Brief wendet sich an Christen, die in Leiden und Anfechtungen stehen'. (The letter directs itself to Christians who suffer and experience temptations.) Reicke (1964) and MacMullen (1966) do more or less the same. They view 1 Peter as an exhortation against Christian participation in anti-Roman activity (like the Jewish Zealot movement). Sleeper (1968:270-286), however, convinces with his argument that this view is not valid. Young (1973:325-338) and Goldstein (1974:88-104) concurs with is not valic
Sleeper.

33.There is solid evidence that this situation changed not many years later. In a letter (c. 110 AD) of Pliny the Younger (Ep. 10.96) to Emperor Trajan and in Trajan's answer to Pliny (Ep. 10.97) the government's involvement in the persecution of Christians is evident. Pliny requests Trajan for guidance on the treatment of Christians, informing him that he had executed those who had admitted that they were Christians but had freed any who denied the charge and who were prepared to sacrifice to the gods and to the do obeisance to the Emperor's statue. The letters do not make clear why those who confessed to being Christians were executed. It could have been because they refused to do obeisance to the Emperor's statue and because of their strange new religion which, although harmless, seemed dangerous to the established Roman Way of Life. Pliny i.a. asks 'nomen ipsum, dangerous to the established Roman Way of Life. Pliny i.a. asks 'nomen ipsum, ' flagitiis careat, an flagitia cohaerentia nomini puniantur' (Or is it the name 'Christian' which is prosecutable, even if not involved in criminal actions, or is that 'criminality' is automatically attached to the name?). In the case of the addressees
of 1 Peter it was especially the last factor, their distinct lifestyle (ávaorpoyńv [conduct]) that caused the local social ostracisation. For an exhaustive utilising of [conduct]) that caused the local social ostracisation. For an exhaustive utilising of
the letter of Pliny in the construction of the circumstances of the addressees of 1 the letter of Pliny in the construction
Peter, see Feldmeier (1992:113-132). 
had the power to excommunicate any such member, leaving that person without the protection and economic security of the household.

The mere fact that they were па́роıко каi парєпıঠ́nно [resident and visiting foreigners] would have impacted negatively on their economic situation. Many of the пápoıкo [resident foreigners] lived outside the cities, working as labourers on the farms of the landowners living in the cities (Rostovtzeff 1957:255-257; Dickey 1928:406; Broughton 1938:628-648).

\section{Teachings and exhortations on economic matters}

Direct teachings and exhortations on economic matters are scarce, which could be an indication that economic matters were not really part of the overt agenda in writing the letter. Only three exhortations touch on economic matters: pertaining to labour (the relationship of the oíḱ'тa। [household servants] with their ठદбпóтaı [employers], 2:18$25)$, the attitude towards greed and earthly goods (nobody must be a thief, $4: 15$ ) and directives to women for the braiding of hair and wearing gold ornaments or fine clothing, 3:3).

\section{Labour}

The pericope 1 Peter 2:18-25 contains explicit exhortations to the оíќтal [household servants] for their relationship with

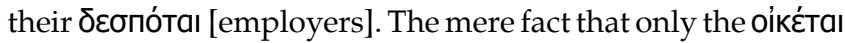
are addressed could be an indication that not many ठєбпо́та counted amongst the addressees. This in itself could signify that many of the addressees shared the economic realities which faced oikétal.

\section{Attitude towards greed and earthly goods}

The author applauds willingness to suffer for what is good. Suffering because of theft, however, is not commended: $\mu$ ì

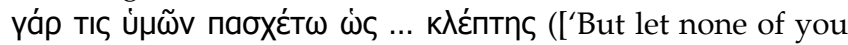
suffer as ... a thief'], 4:15). Theft need not necessarily point to the thief being poor. However, it may be motivated by an urge to survive in a situation of severe poverty.

From the exhortation to wives in 1 Peter 3:3-4 not to adorn themselves outwardly by braiding their hair and by wearing

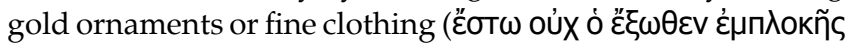

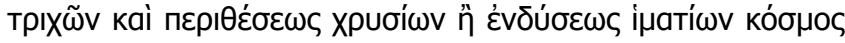
['there should not be outward adornment: arranging of hair and wearing of gold or putting on clothes']), it becomes clear that (at least some of) the addressees had the means to braid their hair and wear jewels and fine clothes. This would indicate households where more than the bare necessities could be afforded and that the women had access to the luxuries mentioned.

\section{Silver and gold}

Precious metals are used twice (gold, 1:7; silver and gold, 1:18), acknowledging its preciousness, but arguing that a spiritual gain is worth much more.
In 1:7 the genuineness of faith is compared with the preciousness of gold: '... so that the genuineness of your faith

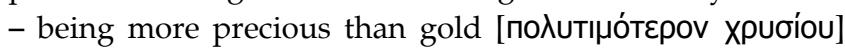
that, although perishable, is tested by fire - may be found to result in praise and glory and honour'. In 1:18 silver and gold are mentioned: 'You know that you were ransomed from the futile ways inherited from your ancestors, not with

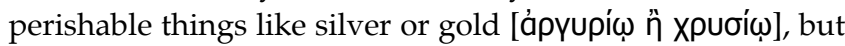
with the precious blood of Christ'.

Not much can be deduced from the mere mentioning of these precious metals. The fact that the author knew he would be understood need not mean that the addressees possessed silver and gold themselves. It is, however, an indication that silver and gold were at least well known in their society and could therefore be used effectively in the comparisons.

\section{Metaphoric use of economic concepts and terminology}

Whilst the teachings and exhortations on economic matters in 1 Peter are scant and commodities such as silver and gold mentioned only once, the metaphoric use of economic concepts and terminology abounds. These function in the imageries

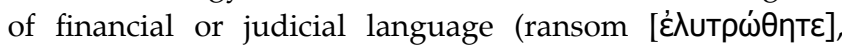

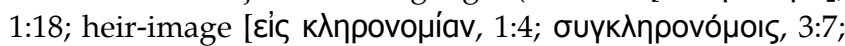

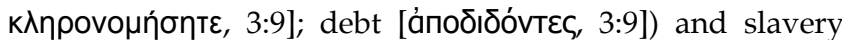

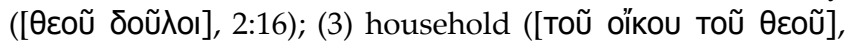

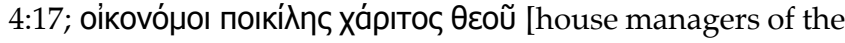
manifold grace of God], 4:10).

\section{Financial or judicial language}

Ransom: In 1:18-19 the author reminds the addressees that they were ransomed with the precious blood of Christ

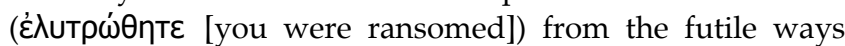
inherited from their ancestors. Although money (or some form of payment) is present in this ransom-image, the image itself gives no window on the economic context of the addressees of the letter, other than that they know the ransoming convention.

Heir or to inherit: The author of 1 Peter uses the heir-image

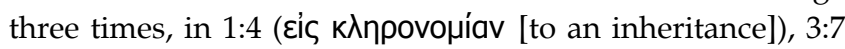

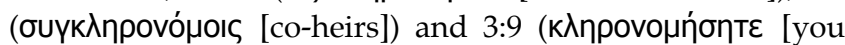
may inherit]).

In 1:4 the author indicates the end goal of God's re-begetting

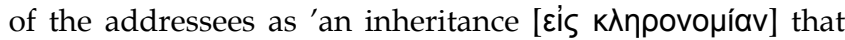
is imperishable, undefiled and unfading, kept in heaven for you'. In 3:7 he uses the same imagery, but now reminding the husbands that their wives are co-heirs with them of the

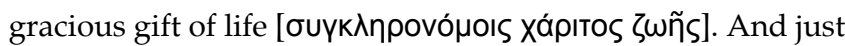
two versus later, in 3:9 the author admonishes the addressees to repay evil and abuse with a blessing, so that they may

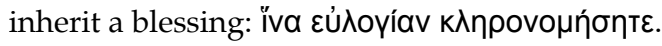

The heir-imagery shows that salvation in 1 Peter represents a present reality and anticipates the complete fulfilment 
thereof in the future. A person that is an heir has this status in the present (see Gl 4:7). ${ }^{34}$ The inheritance itself, however, is future and heirs can have absolute certainty that they will receive this inheritance. ${ }^{35}$ However, the imagery in itself does not really shed light on the economic context of the addressees. At least its use shows that the author had reason to believe that the image would speak to the addressees.

Debt: When exhorting the addressees not to retaliate, the

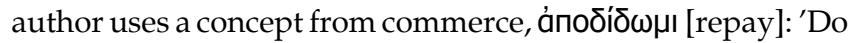

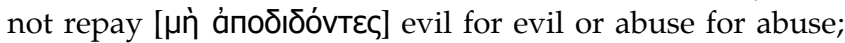
but, on the contrary, repay with a blessing'. This metaphoric use of repayment shows that the addressees were at any rate familiar with the phenomenon of debt.

\section{Slavery}

The author labels the addressees as 'slaves of God' in 2:16:

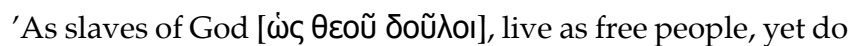
not use your freedom as a pretext for evil'. Nothing much can be deduced from the fact that the author uses this image. At least it shows that the addressees were familiar with slavery.

\section{Household}

The author uses the concepts of 'household' and 'household management' to portray the relationship between the addressees (including himself) and God. In 4:17 he argues that the judgment begins with the household of God (ánò

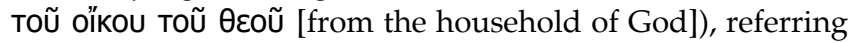
to all Christians. The referent of the 'household of God' is the household that the addressees probably know and are members of. The exhortation in 4:10, that the addressees

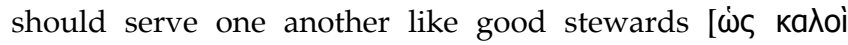
oíkovónol] of the manifold grace of God, with whatever gift each of them has received, also clearly functions within the household image.

Households, both urban and in the countryside, were the principal locus of economic activity and power (Hock 1985). The great urban households were large. ${ }^{36}$ They included not only the householder and his wife, or wives and children,

34. Hammer (1996:416) correctly states that 'the event of Jesus' resurrection makes the hope of future resurrection a present reality and becomes the basis for the future imperishable inheritance'.

35.This differs in some aspects from the definitions given by Louw and Nida (1996), especially because this Lexicon's definition does not allow for the metaphoric use

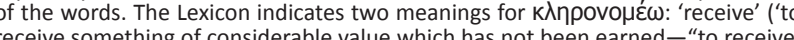
receive something of considerable value which has not been earned- "to receive, to be given, to gain possession of"' Sub-domain 57.131); and 'inherit' ('to receive possession or benefit as a gift from someone who has died, generally a parent-

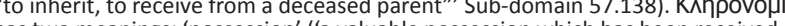
has two meanings: 'possession' ('a valuable possession which has been received"possession"' Sub-domain 57.132); and 'inheritance' ('that which is received from

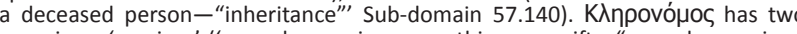
meanings: 'receiver' ('one who receives something as a gift-"one who receives, one who comes into possession of, receiver, heir"', Sub-domain 57.133); and 'heir ('the person who inherits possessions-"heir"' Sub-domain 57.139). All of these meanings are in the group of sub-domains labeled by Louw \& Nida as "'Receive"; the meanings involve a transfer of objects or benefits in which the focus is upon the activity or the experience of the receiver, 57.125-57.141.

36.It is not apparent what the sources of householders' wealth were. Hock (1985) argues for different possibilities. Some wealth originated in the household itself through the work of slave artisans. There were other sources as well: loans ( $\mathrm{Mt}$ $18: 23 ; 25: 20-23$ ), savings (Lk 19:23), tax collections (Lk 3:13; 19:2), not to mention confiscation (Mt 25:24) and hoarding (Lk 12:18). Land was a principal source of wealth. The rich householders of the city were largely a landed aristocracy. Their wealth ultimately came from the agricultural produce of extensive and growing (Mk 12:1; Lk 14:18), holdings beyond the city walls in the countryside. but also slaves (as is evidenced by the household codes both inside and outside of the New Testament). These households might also have contained other persons on occasion or even for extended periods of time. ${ }^{37}$

The referent of household is very clear, but the fact that the author uses this imagery does not disclose what type of households the addressees were members of, or even what their position and function in these households would have been. What is clear, however, is that the addressees knew a household and how it functioned.

\section{Conclusion}

\section{The economic-historic context of the addressees of 1 Peter}

The construction of the economic-historic context of the addressees, taking into consideration 'the minimal data on which any socioeconomic profile of the addressees of 1 Peter' $^{\prime}$ (Horrell 2009:202) can be constructed, could be done quite successfully:

They lived in the districts comprising all of Asia Minor from the Cappadocian Mountains and the Anatolian Highlands down to the Black Sea in the north. The economy was essentially agricultural. The vast majority lived as farmers and herders in the countryside that surrounded a city and worked on land that was usually owned by an urban aristocracy, who lived off its surplus. The two groups, the one producers of wealth, the other consumers of it, were related socially through the institution of the household and surrounded geographically by economically marginal hills, mountains, or deserts, all lumped together as 'wilderness'. There was some, perhaps considerable, commercialisation, but the economy remained fundamentally tied to agriculture. There could also have been the activities of free artisans and shopkeepers in the city (and rural villages) and of brigand gangs in the caves of the wilderness and along its trade routes.

The addressees of 1 Peter were visiting and resident foreigners, people who had formerly been pagans. Most of them had probably had an intermediate state as 'Godfearers', having joined the Synagogue. Their $\pi$ ápoıко [resident foreigners] status impacted negatively on their economic situation. It is possible that many of them shared the economic realities which faced оік乏́тal [household servants]. They may have been so poor that they were drawn to theft. However, there are indications that (some of) the households could afford more than the bare necessities, evidenced by the fact that women had access to luxuries like hair braiding, gold ornaments and fine clothing. Furthermore, silver and gold were well known amongst the addressees and could therefore be used effectively in his comparisons.

37. Hock (1985) gives a list of these 'other persons': rich friends and neighbors invited in for a banquet (Mk 6:21-28; Lk 14:12; 1 Cor 11:17-34); more formal groups, or associations, provided with room and resources for religious and social meetings (Rm 16:1-2,23; 1 Th 5:12; Phlm 1-2); travelers given room and board and perhaps provisions for the next leg of their journey (Ac 21:8; Phlm 22; $3 \mathrm{Jn} \mathrm{5-8);} \mathrm{and} \mathrm{still}$ provisions for the next leg of their journey (Ac $21: 8$; Phlm 22; $3 \mathrm{Jn} 5-8$ ); and still
others, such as teachers and workers, admitted into the household for indefinite periods (1 Cor 9:5-6; see Ac 18:3). 
The metaphoric use of economic concepts and terminology at least indicates that the author expected his addressees to understand the images he used: finance and judicial language (ransom, heir and debt) and slavery and household imagery. This could hardly have been the case if the addressees were abjectly poor.

When these foreigners became Christians, it had positive and negative social consequences. On the positive side, they became part of a Christian group and were no longer isolated individuals or small groups. Those who had been God-fearers and could not become full proselytes were no longer second class members of the new Christian group. The new Christians, however, also had to cope with negative consequences as a result of their new alliance. The unjust suffering which they had to endure as foreigners became even more severe, given that now one more dimension have been added to their 'otherness', the fact that they aligned themselves with an obscure foreign sect.

This resulted in further and more intense ostracisation and discrimination, with the inevitable economic consequences. These circumstances forced them to either retaliate the injustices they suffered or forsake their new commitment to the Christian faith.

The author uses the letter to persuade the addressees of their status before God as saved persons, of the loving care he has for them and of Christ's vicarious suffering and subsequent glory and supreme power. He exhorts them to have a 'good'

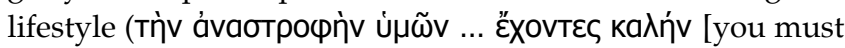
have your lifestyle as a good one], 2:12) and to persevere in doing good ('́v áyaӨonoiíạ [in good-doing], 4:19), even amidst and in spite of their own suffering. In this way they must live up to their status as persons of whom it is said: 0

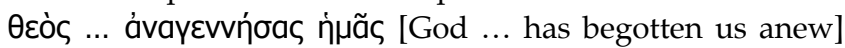
$(1: 3)$.

This means that, whatever their economic status, they could cope, because they had an inheritance kept in heaven.

\section{Summarising the method for the construction of the economic-historic context}

This method first of all entails that the genre of the New Testament letter is discussed, especially the issues of the identity and locality of the addressees, as well as the dating of the letter. This impacts on the spatial and temporal issues involved in constructing the economic-historic context. Then, as the second phase, the argument of the letter is explained, because this becomes a guiding principal in the economic analysis of the letter. The third phase is the construction of the economic-historic context of the addressees, utilising external sources. This enables the researcher to establish the general economic context of the 1st century Graeco-Roman world and to narrow it down to the era and area relevant for the addressees. Then, as the fourth phase, the research returns to the text of the letter. The construction of the third phase is refined, utilising the text of the letter. In this fourth phase the economic relevant portions of the letter are identified, categorised and interpreted. The fifth and final phase is to formulate the economic-historic context of the addressees by synthesising the results of the different phases.

\section{Acknowledgement}

In honour of Andries van Aarde, New Testament scholar, colleague and friend.

\section{References}

Achtemeier, P.J., 1996, 1 Peter. A commentary on First Peter, Fortress Press, Minneapolis.

Applebaum, S., 1974, 'The organization of the Jewish Communities in the Diaspora', in S. Safrai \& M. Stern (eds.), The Jewish People in the First Century: Historical geography, political history, social, cultural and religious life and institutions, pp. geography, political history, socid
464-503, Van Gorcum, Assen.

Aune, D.E., 1987, The New Testament and its literary environment, Westminster Press, Philadelphia.

Alcock, S.E., 2007, 'The Eastern Mediterranean', in I. Morris, R. Saller \& W. Scheide (eds.), The Cambridge Economic History of the Greco-Roman World, pp. 671-697, Cambridge University Press, Cambridge. doi: 10.1017/CHOL9780521780537.026

Balch, D.L., 1981, Let wives be submissive: The domestic code in 1 Peter, Scholars Press, Chicago.

Bassler, J.M., 1991, God and Mammon: Asking for Money in the New Testament Abingdon, Nashville.

Beare, F.W., 1970, The First Epistle of Peter, 3rd edn., Blackwell, Oxford.

Berger, A., 1953, 'Peregrinus', in Encyclopedic Dictionary of Roman Law, vol. 64, part 2, pp. 626-627, The American Philosophical Society, Philadelphia.

Bietenhard, H., 1979a, 'Éźvo ' [Alien], in C. Brown (ed.), The New International Dictionary of New Testament Theology, vol. 1, pp. 686-690, Paternoster Press, Exeter.

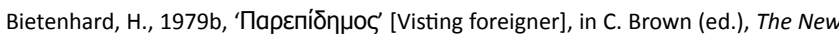
International Dictionary of New Testament Theology, vol. 1, p. 690, Paternoster Press, Exeter.

Bietenhard, H., 1979c, 'Пápoıко ' [Resident foreigner], in C. Brown (ed.), The New International Dictionary of New Testament Theology, vol. 1, pp. 690-691, Paternoster Press, Exeter.

Breytenbach, J.C., 1998, 'Facets if Diaspora Judaism', in A.B. du Toit (ed.), Guide to the New Testament, Volume II: The New Testament Milieu, pp. 327-374, NG Kerk Boekhandel, Pretoria.

Broughton, T.R.S., 1938, Roman Asia Minor, The Johns Hopkins Press, Baltimore.

Brox, N., 1979, Der erste Petrusbrief, Benziger, Zürich.

Cartledge, P.A., 1996, 'Economy, Greek', in Oxford Classical Dictionary, 3rd edn., Oxford University Press, Oxford.

Dickey, S., 1928, 'Some economic and social conditions of Asia Minor affecting the expansion of Christianity', in F.C. Porter, B.J. Bacon \& S.J. Case (eds.), Studies in Early Christianity, pp. 393-416, The Century Co, New York.

Doty, W.G., 1973, Letters in primitive Christianity, Fortress Press, Philadelphia.

Elliott, J.H., 1976, 'The rehabilitation of an exegetical step-child: 1 Peter in recent research', Journal of Biblical Literature 95(2), 243-254. doi: 10.2307/3265239

Elliott, J.H., 1981, A Home for the Homeless: A sociological Exegesis of 1 Peter, its Situation and Strategy, Fortress Press, Philadelphia.

Elliott, J.H., 1986, '1 Peter, its situation and strategy: A discussion with David Balch', in C.H. Talbert (ed.), Perspectives on First Peter, pp. 61-78, Mercer University Press, Macon.

Feldmeier, R., 1992, Die Christen als Fremde: Die Metapher der Fremde in der antiken Welt, im Urchristentum und im 1, Mohr, Tübingen.

Finley, M.I., 1970, 'Aristotle and economic analysis', Past \& Present 70, 3-25. doi: 10.1093/past/47.1.3

Frend, W.H.C., 1967, Martyrdom and persecution in the Early Church, Doubleday, Garden City.

Gnuse, R.K., 1985, You Shall Not Steal: Community and Property in the Biblical Tradition, Orbis, Mayknoll.

Goldstein, H., 1974, 'Die politischen Parënesen in 1 Petr und Rom 13, Bibel und Leben $15,88-104$.

Goppelt, L., 1978, Der erste Peterbrief, 8. Aufl., Vandenhoeck \& Ruprecht, Göttingen.

Grant, R.M., 1977, Early Christianity and Society: Seven Studies, Harper \& Row, San Francisco.

Guthrie, D., 1970, New Testament Introduction, Intervarsity Press, London.

Hammer, P.L., 1996, 'Inheritance (NT)', in D.N. Freedman (ed.), The Anchor Bible Dictionary, vol. 3, pp. 415-416, Doubleday, New York, 
Hanson, K.C. \& Oakman, Douglas E., 2008, Palestine in the Time of Jesus: Socia Structures and Social Conflicts, 2nd edn., Fortress, Minneapolis.

Hengel, M., 1974, Property and riches in the Early Church: Aspects of a social history of early Christianity, Fortress Press, Philadelphia.

Hock, R.F., 1985, 'Economics in New Testament Times', in P.J. Achtemeier (ed.) Harper's Bible Dictionary, Harper \& Row, San Francisco. (Accessed using Libronix)

Horrell, D.G., 2009, 'Aliens and Strangers? The Socio-economic Location of the Addressees of 1 Peter', in B.W. Longenecker \& K.D. Liebengood (eds.), Engaging economics: New Testament scenarios and early Christian reception, pp. 176-202, Eerdmans, Grand Rapids.

Janse van Rensburg, F., 2006, 'A code of conduct for children of God who suffer unjustly: Identity, Ethics and Ethos in 1 Peter', Beihefte zur Zeitschrift für die neutestamentliche Wissenschaft und die Kunde der älteren Kirche 141, 473-510.

Johnson, L.T., 1977, The Literary Function of Possessions in Luke-Acts, Scholars Press, Missoula.

Judge, E.A., 1960, The social pattern of the Christian groups in the first century: Some prolegomena to the study of the New Testament ideas of social organization, Tyndale, London.

Lewis, N. \& Reinhold, M. (eds.), 1966, Roman civilization: Sourcebook II: The Empire, Harper \& Row, New York.

Lohse, E., 1954, 'Paränese und Kerygma im 1. Petrusbrief', Zeitschrift für die Neutestamentliche Wissenschaft und die Kunde der älteren Kirche 45, 68-89. doi: 10.1515/zntw.1954.45.1.68

Longenecker, B.W. \& Liebengood, K.D. (eds.), 2009, Engaging economics: New Testament scenarios and early Christian reception, Eerdmans, Grand Rapids.

Louw, J.P, \& Nida, E.A., 1996, Greek-English Lexicon of the New Testament: Based on Semantic Domains, electronic edn. of the 2nd edn., United Bible Societies, New York.

MacMullen, R., 1966, Enemies of the Roman Order: Treason, unrest and alienation in the Empire, Harvard University Press, Cambridge.

McCaughey, J.D., 1969, 'Three "persecution documents" of the New Testament', Australian Biblical Review 17, 27-40.

Magie, D., 1950, Roman rule in Asia Minor to the end of the third century after Christ; Volume 1: Text; Volume 2: Notes, Princeton University Press, Princeton.

Meikle, S., 1995, Aristotle's Economics, Oxford University Press, Oxford.

Mitchell, S., 1993, Anatolia: Land, Men, and Gods in Asia Minor: The Celts and the Impact of Roman Rule I, Oxford University Press, Oxford.

Morris, I., Saller, R. \& Scheidel, W. (eds.), 2007, The Cambridge Economic History of the Greco-Roman World, Cambridge University Press, Cambridge.

Moule, C.F.D., 1956-1957, 'The nature and purpose of First Peter', New Testamen Studies 3, 1-11. doi: 10.1017/S0028688500017409

Nussbaum, M.C., 1996, 'Economic theory, Greek', Oxford Classical Dictionary, 3rd edn., Oxford University Press, Oxford.

Oakes, P., 2009, 'Methodological issues in using economic evidence in interpretation of Early Christian Texts', in B.W. Longenecker \& K.D. Liebengood (eds.), Engaging economics: New Testament scenarios and early Christian reception, pp. 9-34, Eerdmans, Grand Rapids.

Oakman, D.E., 2008, Jesus and the Peasants, Cascade, Eugene.
Reicke, B., 1964, The Epistles of James, Peter and Jude, Doubleday, Garden City. Richard, E., 1986, The functional Christology of First Peter, in C.H. Talbert (ed.), Perspectives on First Peter, pp. 121-139, Mercer University Press, Macon.

Rostovtzeff, M., 1957, The social and economic history of the Roman Empire, 2nd edn. rev. P.M. Fraser, Clarendon Press, Oxford.

Safrai, S., 1974, 'Relations between the Diaspora and the land of Israel', in S. Safrai \& M. Stern (eds.), The Jewish People in the First Century: Historical geography, political history, social, cultural and religious life and institutions, pp. 184-215, Van Gorcum, Assen.

Saller, R.P., 2007, 'Household and gender', in I. Morris, R. Saller \& W. Scheidel (eds.) The Cambridge Economic History of the Greco-Roman World, pp. 87-112, Cambridge University Press, Cambridge. doi: 10.1017/CHOL9780521780537.005

Schaefer, H., 1949, 'Paroikoi [Aliens]', in Paulys Realencyclopädie der classischen Altertumswissenschaft, neue Bearbeitung, Sechsunddreissigster Halbband Altertumswissenschaft, neue
letztes Drittel, Band 28, vol. 4, pp. 1695-1707, Metzlersche Verlagsbuchhandlung, Stuttgart.

Schmidt, K.L. \& Schmidt, M.A., 1967, 'ПápoIKoc [Alien]', in Theological Dictionary of the New Testament, vol. 5, pp. 841-853, Eerdmans, Grand Rapids.

Schnider, F. \& Stenger, W., 1987, Studien zum neutestamentlichen Briefformular, New Testament Tools and Studies, Brill, Leiden.

Schürer, E., 1973, The history of the Jewish People in the age of Jesus Christ (175 B.C.-A.D. 135), 3 vols., transl. \& ed. G.Vermes, F. Millar, \& M. Black, T\&T Clark, Edinburgh.

Schweiker, W., \& Mathewes, C. (eds.), 2004, Having: Property and Possession in Religious and Social Life, Eerdmans, Grand Rapids.

Seland, T., 2005, Strangers in the light: Philonic perspectives on Christian identity in 1 Peter, Brill, Leiden.

Selwyn, E.G., 1952, The First Epistle of St. Peter, MacMillan, London.

Sidebotham, S.E., 1996, 'Roman Empire', in D.N. Freedman (ed.), The Anchor Bible Dictionary, vol. 6, p. 629, Doubleday, New York.

Sleeper, C.F., 1968, 'Political responsibility according to 1 Peter', Novum Testamentum 10, 270-286. doi: 10.2307/1560001

Stegemannn, E. W. \& Stegemann, W., 1999, The Jesus Movement: A Social History of its First Century, transl. O.C. Dean, Jr., Fortress, Minneapolis.

Stern, M., 1974, 'The Jewish Diaspora', in S. Safrai \& M. Stern (eds.), The Jewish People in the First Century: Historical geography, political history, social, cultural and religious life and institutions, vol. 1, pp. 117-183, Van Gorcum, Assen.

Thurén, L., 1989, ' “Imperative participles” and the rhetorical strategy of 1 Peter', PhD Thesis, Department of Theology, University of Uppsala.

Van Unnik, W.C., 1942 [1980a], 'The Redemption in 1 Peter i 18-19 and the Problem of the First Epistle of Peter', in C.K. Barrett (ed.), Sparsa collecta: The collected essays of W.C. van Unnik, part 2, pp. 3-82, Brill, Leiden.

Van Unnik, W.C., 1956 [1980b], Christianity according to 1 Peter, in C.K. Barrett (ed.), Sparsa collecta: The collected essays of W.C. van Unnik, part 2, pp.111-120, Brill, Leiden.

Young, F.M., 1973, 'Temple cult and law in early Christianity: a study in the relationship between Jews and Christians in the early centuries', New Testament Studies 19 325-338. doi: 10.1017/S002868850000816X 